\title{
Green Architecture Review and the Responsive Building Materials Towards a Sustainable Built Environment in Nigeria
}

\author{
Jonam Jacob Lembi ${ }^{1, ~ *}$, Ibrahim Adamu Umar ${ }^{1}$, Hilsang Alfred Kobiba ${ }^{2}$, Amos Musa Tarni ${ }^{3}$ \\ ${ }^{1}$ Department of Architecture, Federal University of Technology, Minna, Nigeria \\ ${ }^{2}$ Department of Civil Engineering, Taraba State University, Jalingo, Nigeria \\ ${ }^{3}$ Department of Architecture, University of Jos, Jos, Nigeria
}

Email address:

j.lembi@futminna.edu.ng (J. J. Lembi)

${ }^{*}$ Corresponding author

\section{To cite this article:}

Jonam Jacob Lembi, Ibrahim Adamu Umar, Hilsang Alfred Kobiba, Amos Musa Tarni. Green Architecture Review and the Responsive Building Materials Towards a Sustainable Built Environment in Nigeria. International Journal of Architecture, Arts and Applications. Vol. 7, No. 3, 2021, pp. 71-76. doi: 10.11648/j.ijaaa.20210703.13

Received: July 1, 2021; Accepted: July 15, 2021; Published: August 23, 2021

\begin{abstract}
The high cost of construction materials in Nigeria has become a serious problem of obtaining a decent environment especially for the low income earners who find it very difficult to construct an affordable decent house. It is more serious for the low-income groups whose challenges are complicated by several factors including the ever increasing cost of construction materials. Citizens cannot afford decent materials for their building construction which makes the environment polluted and difficult to have an environmentally responsive buildings. The study aims at identifying potentials of sustainable building materials in addressing Green Architecture and Affordable housing construction in Nigeria through the review of principles of Green Architecture and sustainable building materials. The purpose of the review is to compile the available data of different sustainable building materials found in Nigeria that would be used alternatively to reduce the cost of building materials thereby enhancing Green Architecture in the built environment. The study employed the use of qualitative data analysis from relevant literature. The review showed that, the re-use of existing local materials found in Nigeria provides ecofriendly environment and promotes the effectiveness of building economics. The efficiency of energy, water and resource control has become relevant element in the promotion of green architecture and sustainable built environment. Sustainable materials to lower cost of construction are best described in their resource efficient, made from renewable materials and it is non-toxic.
\end{abstract}

Keywords: Cost of Construction, Green Architecture, Housing, Nigeria, Sustainable Building Materials

\section{Introduction}

Green Architecture is a green building design technique. The designs are formed with the environment in point comprising concentrating on the greater construction effects of environmental sustainability. Green Architecture gives cautious attention to planning eco-friendly and energy efficient houses and buildings. Natural ecology is a main perception in green architecture providing the foundation for the construction model [11]. The goal of green architecture has been identified by the green register, to produce simulations that protect the regular surroundings and are transformed to assimilate with the present environmental scenery in relation to space and energy, water and use of resources. The green architecture designs must be sustainable at the first stage of consultations, modification of plan, design and site survey, the use of materials, coherence with ecology in existence, the choices of green building to warrant the inclusiveness of environmental details that are really friendly to the eco-system.

The efficiency of thermal tolerance, energy, water, reserve and cost of construction are important components used in green architecture. The finest materials used in green buildings and architecture constitutes the Accoya modified 
wood is richly found Nigeria. It is very efficient in the resource use, sustainable and durable, it comes from recycled materials and is not harmful to human health [7]. The recycled materials used in green architecture fosters the sustainability driven factor of conducive and healthy environment. Flexible and healthy materials that are recycled for sustainable built environment are picked from material character of stone, steel, newspapers, cardboards, demines and insulated cotton. They are flexible and efficient because they require lesser energy of production, few additive chemicals, and good compliance to global warming of less carbon print which lessens air pollution and improves on the air quality of the built environment. Wood chips or slag, concrete gotten from crush glass are good examples of such sustainable materials [24]. Original, rich or renewable materials can be gotten from sustainably accomplished and naturally occurring sources. They need to be renewable and sufficiently plentiful in nature, examples are solar tiles and certified wood. Other renewed, recovered materials are intrinsically capacitated to create value and valid materials from discarding or landfill waste generation. The due action of these materials are repaired or improved upon, or renovated and recycled to improve productivity, efficiency, and functionality. Plastic ceilings are said to be good examples of such renewable building material [13].

Across the globe, European studies suggest that buildings are responsible for around $45 \%$ of global carbon dioxide emissions over the entire life cycle [21]. More so, this percentage has increased every year by $1 \%$ since 2010 [12]. United Nations Government standards for determining Green House Gas (GHG) emission identifies a known fact that carbon dioxide as well as other greenhouse gasses (GHG) such as methane and nitrous oxide contribute to global warming. Climate change can also be seen in changes to precipitation (rainfall) and future climate change will cause seal levels to rise, increase acidity of our seas, bring about differences in precipitation from one region to the other and lastly cause expansion of deserts in sub-tropical areas of the world. Asides from the effects of climate change, overpopulation and urbanization continues to reduce green space [19]. Some challenges associated to the adoption of green architecture is the limitation of green products and materials in the building construction industry [27].

Over the last few years, Nigeria has experienced its share of debilitating effects of climate as seen in floods and rising temperatures. If Nigeria encourages green buildings, the impact of global warming/climate change globally will reduce [14]. An article in the Living Architecture Monitors, suggests that with astounding air pollution levels and other environmental problems that are present, we must take the path of green walls and green roofs. The environmental benefits of Green roofs are enormous, like acting as a sponge absorbing rainfall which can help reduce runoffs, providing natural cooling properties and lowering the effects of sound reflection. In addition, green roofs help reduce rain water; keeping them out of sewers, encourages bio diversity; like attracting birds, bees and other life form. Social benefits of green roofs includes health and wellbeing of people who work in green offices or green homes; research suggests that better indoor air quality can lead to improvements in performance for up to $8 \%$ [14]. The difference between Green roofs and Green walls is the location of vegetation/plants on the building. For green roof, vegetation/plants are on the roof, while for green walls, vegetation/plants are on the walls. The vegetation/plants used on the walls are preferably climbing plants, walls are now being constructed that can support vegetation. Its advantages are same on the green roofs. One of its astounding social benefits is its aesthetic quality; green walls beautify the surroundings of a community. Else, an interesting economic benefit of green roofs and walls on a building, whether aged or modern of refurbished commands a $7 \%$ increase in the amount of money valued over buildings that are not green. Moreover, walls that are strategically placed can substantially improve indoor air quality as well as circulation, likewise, it helps in reducing ultra-violet radiation which can damage the building [14]. The sustainable energy potential of Nigeria encourages the adoption of green architecture concept [25].

In 2014, an attempt was made in Lagos to erect the first green building in Nigeria. A lot more can be done, we can't afford to miss out on its tremendous benefits. Green buildings benefit to the environment include protection of the ecosystem and biodiversity, improve water and air quality, reduce waste, preservation, and restoration of natural and renewable resources, and reduce heat gain [23]. More awareness should be given to the public with effective enlighten factors from the Nigerian government in order to promote Green Architecture [26].

\section{Principles of Green Architecture}

Energy efficiency is a factor in green architecture where efficiency in green design emphasizes on the energy reduction in building utilities from the action of optimization of natural lighting, ventilation and other power consuming components of electrical energy. This means when buildings consume less energy, individual will make saving on energy cost [7]. Energy efficient buildings has been defined as those building that strives towards the lowest possible energy requirement with reasonable utilization of resources using energy efficient measures [18]. Energy efficient can be regarded as the first step toward achieving sustainability in buildings. It helps to minimize rising energy cost, enhance the value and competiveness of buildings and reduce greenhouse gases emission. Interest in environmentally responsible buildings commenced around the middle of the last century owing to the ambition of several communities that advocate green buildings consequent to the need for an ecological world [7].

Water efficiency adheres to green architectural duties with the aim of surrounding environment to preserve the quality of water and minimize wastage. The conceptual design from architects and engineers should cater for the life span of the building envelope through sustainable mechanical 
specifications that the recycled mechanism of water would be efficient. Land use act and other land regulatory bodies should make the developmental plans of land active and enforceable to preserve and maintain the environment ad to make use and re-use of locally found materials. Incorporating green walls, green roofs, roof garden, and earth shelters through proper landscaping around the building environment [9]. Improper adherence to Environmental Impact Assessment (EIA) has been proven to be the major factor carrying $50 \%$ of environmental destruction which relates to the poor construction process in the building industry and devastation of projects. $10 \%$ of global emission every year is said to have generated from the construction of projects. The principle of green architecture which therefore, caters for low environmental impact assessment through efficiency of material use, cost of maintenance, waste reduction and the use of renewable energy to improve indoor air quality and outdoor environmental quality [8].

\section{Methodology}

The study presents a systematic literature review on Green Architecture assessment with reference to sustainable building materials found in Nigeria, following Preferred Reporting Items for Systematic Reviews and Meta-Analyses (PRISMA) guidelines. After a search for literature, the research employed a content analysis to identify themes and organize qualitative data from the literature to better understand how sustainable building materials enhance green architecture in Nigeria.

\subsection{Data Collection}

Haven identified the Preferred Reporting Items for Systematic Reviews and Meta- Analyses (PRISMA). The data used in this assessment were collected from a secondary source. Firstly, data on six sustainable building materials from Agro-Industrial wastes in Nigeria, the 2019 development by Abel Olajide Olurunnisola and secondly, data on various analysis of the six materials were collected from Alsop, Post, Parry J., Agopyan, Reis, Fernandez J. E, Chakravarthi, Ogunjobi, Liu, Amo, Akinyele and cement company of Nigeria.

\subsection{Method of Assessment}

Various analysis were carried out on the identified data from literatures and the principles of green architecture. The properties of the six building materials were compared based on their water absorption properties, breaking load test, compressive strength, physical properties, thickness, swelling, reinforcement, modulus of elasticity and rapture.

\section{Results and Discussion}

The results identified the six building materials to be responsive towards addressing Nigeria's green architecture, a sustainable built environment and the quest for affordable housing construction. Thus, the sustainable materials identified:

1. Pozzolans and blended cement

2. Natural fibre-reinforced roofing tiles

3. Cement-bonded composite ceiling boards

4. Saw dust-reinforced concrete hollow blocks and clay bricks

5. Natural fibre-reinforced floor and wall tiles

6. Concrete beam reinforcement

\subsection{Pozzolans and Blended Cement}

In Nigeria, numerous agricultural remains are easily obtainable and frequently treated as wastes. Examples include bagasse (waste obtained from sugar cane (Saccharum officinarum) processing) and corn (Zea mays) cobs (Olurunnisola, 2019). The pozzolanic actions of the remains of these two deposits have been tried and confirmed. It is stated that a Corn Cob Ass (CCA) blended cement containing not more than $15 \%$ of CCA fulfils the NIS 439:2000 and ASTM $\mathrm{C}_{150}$ condition for cement. The compressive strength and workability of CCA-blended cement concrete comprises more than $8 \%$ of $\mathrm{CCA}$ is appropriate for structural concrete works [17].

Table 1. Comparison of Cement and Pozzolan Properties.

\begin{tabular}{lllll}
\hline & Cement & Pozzolan & Fly Ash & Slag \\
\hline Calcium oxide (\%) & 65.0 & 5.0 & 5.0 & 40.0 \\
Magnesium oxide (\%) & 1.5 & 2.0 & 2.0 & 5.0 \\
Silica Dioxide (\%) & 20.0 & 60.0 & 45.0 & 35.0 \\
Aluminium oxide (\%) & 6.0 & 15.0 & 20.0 & 15.0 \\
Ferrous oxide (\%) & 2.5 & 5.0 & 10.0 & 0.3 \\
Bulk Density $\left(\mathrm{t} / \mathrm{m}^{2}\right)$ & 1.5 & 1.6 & 1.0 & 1.8 \\
\hline
\end{tabular}

Source: [3].

Table 1 shows the various chemical content of cement and pozzolan. The various property content identifies an important reason for being good resistance to attack by chemical agents, especially sea water, and by sulphate-rich water thus contributing to the reduced use of naturally occurring raw materials, and less energy is consumed in their production compared with the production cement clinker, reducing greenhouse-gas emission and the overall $\mathrm{CO}_{2}$ footprint. The samples studied were taken from the Kalambaina quarry 1 former Sokoto state of Nigeria (now Sokoto, Kebbi and Zamfara states) [5].

\subsection{Natural Fibre-Reinforced Roofing Tiles}

Research on the development of materials that are sustainable to substitute materials for roofing gotten from composites of wood fibre cement have been going globally over the period of 30 years [1]. Africa has quite a good measure of fibre which has its major source to rattan for cement-bonded roofing tile fabrication, a considered collection of flaking fruited, spiny, rising palms with flexible stem generally originate close to water courses 20 and more African countries including Nigeria. Additional fibrous materials already studied and found appropriate for cement- 
bonded composite roofing tile production in Nigeria include coconut husk, sugar cane bagasse, bamboo, raffia palm and luffa [17].

Table 2. Water Absorption Properties of Natural Fibres.

\begin{tabular}{llll}
\hline Natural Fibre & $\begin{array}{l}\text { Dry weight } \\
\text { (kg) }\end{array}$ & $\begin{array}{l}\text { Wet weight } \\
\text { (kg) }\end{array}$ & $\begin{array}{l}\text { \% of } \\
\text { absorption }\end{array}$ \\
\hline Coir Reinforced Tiles & 2.847 & 3.022 & 6.14 \\
Banana Reinforced Tiles & 2.811 & 3.003 & 6.37 \\
Sugarcane Reinforced Tiles & 2.925 & 3.034 & 6.38 \\
\hline
\end{tabular}

Source: [6].

Result from Table 2 shows clearly from the water absorption test that the quantity of absorption of water is very much less in coir fibre tiles when compared to other two fibre tiles.

Table 3. Breaking Load Test of Natural Fibre.

\begin{tabular}{llll}
\hline \multirow{2}{*}{ Tiles Specimen } & $\begin{array}{l}\text { \%o of } \\
\text { Fibre }\end{array}$ & \multicolumn{2}{c}{ Breaking Load in N/mm } \\
\cline { 3 - 4 } & 0 & 7 days & 28 days \\
\hline Standard Cement Tiles & 15 & 25.45 & 25.23 \\
Coir Reinforced Tiles & 15 & 23.78 & 28.21 \\
Banana Reinforced Tiles & 15 & 21.32 & 26.65 \\
Sugar Cane Reinforced Tiles & 15 &
\end{tabular}

Source: [6].

From Table 3, the test shows clearly that when $15 \%$ of coir fibre is reinforced with concrete, it shows that the best Breaking Load $\left(30.21 \mathrm{Nm}^{2}\right)$ as compared to reinforced banana and sugarcane fibre.

\subsection{Cement-Bonded Composite Ceiling Boards}

Cement-bonded particle board is a broad term for a panel product contrived from lignocelluloses mainly in the usage of distinctive pieces or particles, combined with cement and compacted [20]. Some of the splendid properties of cementbonded particles boards comprise relatively high strength to water weight ratio and durability, high resistance to moisture uptake, nail ability and comfort of sawing; brilliant insulation against noise and heat; and high resistance against fire, insect and fungus attack [17]. Ceiling boards have been factorymade from a quantity of lignocellulosic fibres and wastes in Nigeria including sawdust, waste paper, rattan cane, coconut husk, maize husk, elephant grass, pawpaw, pseudo stem, and okra.

Table 4. Mean Value of Water Absorption and Thickness Swelling from Boards Produced from Anogeissus leiocarpuss Sawdust.

\begin{tabular}{lll}
\hline Mixing Ratio & Water Absorption (\%) & Thickness Swelling (\%) \\
\hline $3: 1$ & $135.76 \pm 20.49^{\mathrm{b}}$ & $16.67 \pm 11.54^{\mathrm{a}}$ \\
$1: 1$ & $118.07 \pm 19.55^{\mathrm{b}}$ & $11.67 \pm 6.38^{\mathrm{a}}$ \\
$1: 3$ & $24.95 \pm 1.98^{\mathrm{a}}$ & $10.00 \pm 3.85^{\mathrm{a}}$ \\
\hline
\end{tabular}

Source: [16].

Table 4 shows the mean values of Water Absorption (WA) and Thickness Swelling (TS) of the cement-bonded boards soaked in water for 24 hours. According to the results obtained, water absorption rate with $135.76 \%$ produces the highest thickness of $16.67 \%$ to ratio $3: 1$ ( $75 \%$ sawdust: $25 \%$ cement).

Table 5. Mean Values of Modulus of Elasticity and Modulus of Rapture from Boards Produced from Anogeissus leiocarpus Sawdust.

\begin{tabular}{lll}
\hline $\begin{array}{l}\text { Mixing } \\
\text { Ratios }\end{array}$ & $\begin{array}{l}\text { Modulus of Elasticity } \\
\left(\mathbf{N m m}^{-2}\right)\end{array}$ & $\begin{array}{l}\text { Modulus of Rapture } \\
\left(\mathbf{N m m}^{-2}\right)\end{array}$ \\
\hline $3: 1$ & $23.39 \pm 1.90^{\mathrm{a}}$ & $0.20 \pm 0.02^{\mathrm{a}}$ \\
$1: 1$ & $76.99 \pm 27.84^{\mathrm{a}}$ & $0.63 \pm 0.19^{\mathrm{a}}$ \\
$1: 3$ & $343.12 \pm 149.97^{\mathrm{b}}$ & $2.36 \pm 0.65^{\mathrm{b}}$ \\
\hline
\end{tabular}

Source: [16].

Mean in columns with different superscript denotes significant difference $(\mathrm{P} \leq 0.05)$

The results from Table 5 showed that mean MOE was highest $\left(343.12 \mathrm{Nmm}^{-2}\right)$ in boards made from 1:3 mixing ratio and lowest $\left(23.39 \mathrm{Nmm}^{-2}\right)$ in boards made from $3: 1$ sawdust/cement mixing ratio. It was observed that mean value for MOR was highest $\left(2.36 \mathrm{Nmm}^{-2}\right)$ in boards made from 1:3 sawdust/cement mixing ratio. There was also no significant difference between boards produced from $3: 1$ and 1:1 sawdust/cement mixing ratios but $1: 3$ was significantly different $(\mathrm{P} \leq 0.05)$ from others. Findings showed that Anogeissus leiocarpus sawdust was suitable for production of cement bonded particle boards which could be used as ceiling board as well as in partitioning panels.

\subsection{Sawdust-Reinforced Concrete Hollow Blocks and Clay Bricks}

To lessen the cost of concrete hollow blocks, integrating Nigerian Tectona grandis sawdust and partial replacement of cement with residue of calcium carbide and egg shell of poultry products powdered in the mix for the production of low-cost concrete hollow blocks was established to be sustainable [17].

Table 6. Compressive Strength of Grout-filled Saw dust.

\begin{tabular}{llll}
\hline $\begin{array}{l}\text { Specimen } \\
\text { No. }\end{array}$ & $\begin{array}{l}\text { Ultimate Load } \\
(\mathbf{K N})\end{array}$ & $\mathbf{A g}\left(\mathbf{m m}^{2}\right)$ & $\begin{array}{l}\text { Stress at Ultimate } \\
(\mathbf{m p a})\end{array}$ \\
\hline 1 & 616 & 43548 & 14.1 \\
2 & 693 & 42645 & 16.3 \\
3 & 781 & 43967 & 18.1 \\
4 & 640 & 42903 & 14.9 \\
Average & 683 & 43266 & 15.9 \\
\hline
\end{tabular}

Source: [15].

Table 6 results identifies the average ultimate load of 683 at 15.9 stress at ultimate which shows the advantages of Sawdust Concrete Units (SCUs) that can readily accept ordinary screws and nails. Back-up walls for brick veneer that are made of SCUs display overall better compatibility, ductility and strength properties that are displayed by steel stud back-up walls. It is established that SCUs have better binding properties with mortar and grout than making it stronger. 


\subsection{Natural Fibre-Reinforced Floor and Wall Tiles}

Recent and sustainable concrete tiles are prepared from the mixture of Portland cement and quarry sand as an aggregate. The main benefit of fibre reinforcement of concrete tiles is to influence additional energy-absorbing ability and to convert a brittle material into a pseudo ductile material. One of the sources of natural fibres found throughout West Africa and freely obtainable in Nigeria is Cissus populnea [10].

Table 7. Physical Properties Cissus populnea Fibre.

\begin{tabular}{ll}
\hline Properties & Value \\
\hline Mean M. C (\%) & 16 \\
Mean Bulk Density $\left(\mathrm{g} / \mathrm{cm}^{3}\right)$ & 0.15 \\
Mean Water Absorption (\%) & $226(2 \mathrm{hr}),$.375 (24hr.) \\
\hline
\end{tabular}

Source: [4].

Table 7 shows the percentage water absorption of the fibres after 2 and 24-hour soaking periods $226 \%$ and $375 \%$ respectively. These value are comparable with the water absorption rates of other known fibres that have been used for composite making such as Sisal fibre (110\%), Coir fibre (98\%), Bamboo fibres (145\%), and Banana fibres (407\%) as reported by Torgal and Said (2002). Binding the components of natural fibre in reinforced floor and wall tiles adheres to single component polymer latex modified tile adhesive.

\subsection{Concrete Beam Reinforcement}

Substitute reinforcing materials have progressed to bind strength of canes of particular rattan species in concrete was examined and revealed. The strength could be up to roughly $30 \%$ of that concrete and mild steel. The usage of entire canes, fibres and splits of rattan canes as reinforcement materials in concrete slabs was also examined. Rattan canes is stable and in strength and dimension and could be used in reinforcement in lightly loaded structures. Other appropriate constituents for reinforcement are bamboo, rattan cane. The average compressive strength of the bamboo and rattan reinforced struts stands at 78 and $64 \%$ of the equivalent steel reinforcement, signifying that both materials could be used as replacement for steel in struts of low load bearing structures [17].

Table 8. Reinforcement Comparison of Rattan, Bamboo and Steel.

\begin{tabular}{lll}
\hline Reinforcing Materials & $\begin{array}{l}\text { Average Ultimate } \\
\text { Load (KN) }\end{array}$ & $\begin{array}{l}\text { Average Crack } \\
\text { width (mm) }\end{array}$ \\
\hline Rattan & 94.82 & 2.80 \\
Bamboo & 116.78 & 1.38 \\
Steel & 149.38 & $1.6 \mathrm{~m}$ \\
\hline
\end{tabular}

Source: [2].

Table 8 shows the various capacity of reinforcement in Rattan, Bamboo and Steel. Bamboo and rattan cane can be used as alternative to steel in light construction at low cost for areas where steel reinforcement is needed.

\section{Recommendation}

The study recommends Nigerian government to create a sub-unit under the Federal Ministry of Agriculture to be responsible for collection of agricultural residues to be converted into sustainable building materials.

The use of green architectural materials like Accoya modified wood, paper insulation from recycled newspapers and cardboards, cotton insulation from recycled demines, natural fibre, recycled stones and recycled steel are effective because they use fewer chemicals and energy to process and also require fewer virgin resources.

The Nigerian government should encourage the use of bamboo, coconut husk, sugarcane bagasse, raffia palm and luffa to be suitable for cement-bonded composite roofing tile production in Nigeria.

The use of Anogeissus leiocarpus sawdust should be encouraged because it is suitable for production of cement bonded particle boards which could be used as ceiling board as well as in partitioning panels.

The study recommends sawdust and partial replacement of cement with calcium carbide residue and poultry egg shell powder in the mix for the production of low-cost concrete hollow blocks.

The use of sawdust concrete units that can readily accept ordinary screws and nails should be encouraged, they have better binding properties with mortar and grout than making it stronger.

Bamboo and Rattan cane can be used as alternative to steel in light construction at low-cost. Rattan canes is stable and in strength and dimensions and could be used in reinforcement in lightly loaded structures.

Fibre reinforced concrete tiles should be used to impact additional energy-absorbing capability.

The legislative arm of government should create laws that would encourage the use of materials that has good thermal performance, energy efficiency, water efficiency, resource management and save general construction cost.

\section{Conclusion}

Affordable housing and sustainable built environment in Nigeria can be achieved through the adaptation of the principles of green architecture and sustainable building materials. The materials used in green architecture provides good thermal performance, energy efficiency and save general construction cost. Their recycled character, re-use of existing local materials provides an eco-friendly environment and helps to minimize rising energy cost, enhance the value and competiveness of buildings and reduce greenhouse gas emission. Naturally fibred materials are proven to have low cost, lesser production energy, and serve the purpose of other building materials that are expensive to purchase. The fibre and local materials are richly available in Nigeria and when put in active use, it shall reduce the cost of construction and housing problem in Nigeria. 


\section{References}

[1] Agopyan, V., Savastanojr, H., John, V., Cincotto, M. (2005). "Development of Vegetable Fibre-cement Based Materials in Sao Paulo, Brazil: An overview”. Cement Concrete Compos, 27 (5): 527-536.

[2] Akinyele, J. O. and Aresa, S. W. (2013). "Structural Characteristics of Bamboo and Rattan Cane Reinforced Concrete Struts" retrieved from www.sciencedomain.org on February $16^{\text {th }}, 2021$. pp. 689.

[3] Alsop, P. A. and Post, J. W., (1995). The Cement Plant Operations Handbook for Dry Process Plants, $1^{\text {st }}$ Edition. Tradeship Publications.

[4] Amoo, K., Adefisan, O. O. and Olurunnisola, A. O. (2016) Development and Evaluation of Cement Bonded Composite Tile Reinforced with Cissus populnen Fibres". Amoo K. et al. Retrieved from research gate $16^{\text {th }}$ February, 2021. (pp. 134139).

[5] Cement Company of Nigeria, (1981). Geological Survey of the Limestone Deposits CCNN, Sokoto, Nigeria.

[6] Chakravarthi, P., Karthikeyan, A., Kumar, P., Prakash, R. and Karthik, G. (2019). "Analysis of Reinforced Natural Fibre Cement Composite Roofing Tiles" Accessed from http://ijesc.org/ Retrieved February $18^{\text {th }}, 2021$.

[7] Charles, J. K. (2008). "Sustainable Construction of Green Building Design and Delivery". Edition 2, 241-249.

[8] Chung, W. (2006). "Benchmarking the Energy Efficiency of Commercial Building" Chung et al. Retrieved from www.sciencedomain.org on March $5^{\text {th }}, 2021$.

[9] Etiosa, U. (2009). "Energy Efficiency Survey in Nigeria: A Guide for Developing Policy and Legislation”. Etiosa U. et al. Retrieved from research gate $20^{\text {th }}$ February 2021.

[10] Fernandez, J. E. (2002). Flax Fibre Reinforced Concrete- A Natural Fibre Bio Composite for Sustainable Building Materials, in High Performance Structures and Materials C. A. Brebbia and W. P. Wilde, Editors Seville, pp. 193-207.

[11] Green Register (2014). "Essential and Features for a Successful and Sustainable Building". Available from the Green Register htt://www.greenregister.org.uk/pro-essential. Retrieved March $10^{\text {th }}, 2021$.

[12] Global Environmental Policies, United Nation Government, 2010.

[13] Kim, J. J. (2008). "Qualities, Use, and Examples of Sustainable Building Materials". Michigan: National Population Prevention Centre for Higher Education.

[14] Kim, J. and Yoon, Y. (2011). "Economic Analysis and Energy Reduction by the types of Green Roof" Seoul Studies 12 (12), pp. 125-140.
[15] Liu, Y., Dave, J. and Christie, G. (2005). "Evaluation of Lightweight Sawdust Concrete Units" Canadian Masonry Symposium, Banff, Alberta, June 8-12, 2005. Retrieved from Canadamasonrydesigncentre.com $11^{\text {th }}$ February, 2021.

[16] Ogunjobi, K. M., Ajibade, M. A., Gakenou, O. F. and Gbande, S. (2019). "Physical and Mechanical Properties of CementBonded Particle Board Produced from Anogeissus leiocarpus (D. C) Guill and Perwood species" Retrieved from African Journal of Agriculture Technology of Environment Vol. 8 (1): 192-199, June, 2019.

[17] Olurunnisola, A. O. (2019). "Development of Sustainable Building Materials from Agro-Industrial Wastes in Nigeria" Available from www.intechopen.com: https://www.intechopen.com/books/sustainable-constructionand-building-materials/development-of-sustainable-buildingmaterials-from-agro-industrial-wastes-in-nigeria. Retrieved March $16^{\text {th }}, 2021$.

[18] Radhi, H. (2008). A Systematic Approach for Low Energy and Buildings in Bahrain $(\mathrm{PhD})$.

[19] Reis, JML (2006). "Fracture and Flexural Characterization of Natural Fibre-Reinforced Polymer Concrete". Construction of Building Material, 20 (9): 673-678.

[20] Torgal, F. P. and Said, J. (2002). Vegetable Fibre Reinforced Concrete Composite. A publication The C-TAC Research Unit, University of Minlo, Guimaraes, Portugal.

[21] United Nations Environmental Programme, 2007. Frame work Conference on Climate Change.

[22] United Nations Government Standards for Determining Greenhouse Gas Emission for Cities.

[23] U.S. Environmental Protection Agency (2010). Green Building Basic Information. Retrieved from http://www.epa.gov/greenbuilding/pubs/about.htm. $\quad 20^{\text {th }}$ February, 2021.

[24] Varis, B. and Maria, B. (2010). "The Whole Building Handbook, How to Design Healthy, Efficient and Sustainable Buildings.

[25] Okeke, F. O. Chinwe, S., Okafor, C., Andy, N. N., Ani, E. K., Okere, C. E. and Ugwu, C. C. (2018). Green Architecture and the Nigerian Perspective. International Journal of Agriculture, Environment and Bioreseaech. 3 (6): 341-351.

[26] Koko, A. F. and Muhammed, B. (2020). “ The Green Approach to Architecture Exploring the Factors Hindering the use of Green Architecture in Nigeria" Auwal, F. K. et al. Retrieved from intechopen $10^{\text {th }}$ July, 2021.

[27] Cole, L. B. (2019). Green Building Literacy: A Framework for Advancing Green Building Education (2019). International Journal of STEM Education. Cole, L. B. et al. Retrieved from journal. Springeropen.com $10^{\text {th }}$ July, 2021. 